\title{
Uridine diphosphate glucuronosyl transferase 1A (UGT1A1) promoter polymorphism in young patients with sickle cell anaemia: report of the first cohort study from Nigeria
}

\author{
Oladele Simeon Olatunya ${ }^{1,2^{*}}$ (D), Dulcineia Martins Albuquerque ${ }^{1}$, Ganiyu Olusola Akanbi ${ }^{3}$, \\ Olufunso Simisola Aduayi ${ }^{3}$, Adekunle Bamidele Taiwo ${ }^{4}$, Opeyemi Ayodeji Faboya ${ }^{5}$, Tolorunju Segun Kayode ${ }^{6}$, \\ Daniela Pinheiro Leonardo ${ }^{1}$, Adekunle Adekile ${ }^{7}$ and Fernando Ferreira Costa ${ }^{1}$
}

\begin{abstract}
Background: (TA) n repeat sequence (rs8175347) of UGT1A1 gene promoter polymorphism is associated with serum bilirubin levels and gallstones among different sickle cell anaemia (SCA) populations. There are no data on UGT1A1 polymorphisms and their impact on Nigerian SCA patients. In this study, we determined the distribution of the UGT1A1 (TA) n genotypes among a group of young Nigerian SCA patients and healthy controls. In addition, the influence of UGTIA1 (TA) $n$ genotypes on the laboratory and clinical events among the patients was determined.

Methods: The distribution of the UGT1A1 (TA) n genotypes among 101 young Nigerian SCA patients and 64 normal appropriate controls were determined and studied. The UGT1A1 (TA) n genotypes were further classified into subgroups and used to differentiate the clinical events and laboratory parameters of the patients.
\end{abstract}

Results: Four (TA) n alleles:(TA)5, 6, 7, and 8 were found. These were associated with 10 genotypes: TA5/5, 5/6, 5/7, 5/8, 6/6, 6/7, 6/8, 7/7, 7/8, 8/8. The normal (wild-type)-(TA) 6/6), low- (TA) 7/7, 7/8, 8/8), intermediate- (TA) 5/7, 5/8, 6/7, 6/8), and high-activity (TA) 5/5,5/6, genotypes were found in $24.8,24.8,41.5$, and $8.9 \%$ patients and $20.3,15.6,61$, and $3.1 \%$ controls respectively. The general genotype distribution of the patients and control group were not significantly different. There were significant differences in serum bilirubin and lactate dehydrogenase (LDH) of the patients when differentiated by the UGT1A1 (TA) n genotypes $(p<0.05)$. Asymptomatic gallstones were found in $5.9 \%$ of patients and were significantly of the low-activity genotypes sub-group 5 (20\%) vs $1(1.3 \%) p=0.0033$. Although, bilirubin and fetal hemoglobin $(\mathrm{HbF})$ of patients with gallstones were significantly different from those without gallstone, only the serum bilirubin was associated with UGT1A1 (TA) n genotypes on multivariate analysis $(p<0.0001)$.

Conclusion: This study highlights the contribution of UGT1A1 polymorphisms, a non-globin genetic factor, to the laboratory and clinical manifestations of young Nigerian SCA patients for the first time. It also shows that children with co-inheritance of low UGT1A1 (TA) $n$ affinity genotypes may be at risk of gallstone, hence the need to follow them up.

Keywords: Sickle cell anaemia, Laboratory parameters, Clinical events, Gallstone, UGT1A1 polymorphism, Nigeria

\footnotetext{
*Correspondence: ladeletunya@yahoo.com; simeon.olatunya@eksu.edu.ng

'Hematology and Hemotherapy Center (Hemocentro), University of

Campinas (UNICAMP), Rua Carlos Chagas, 480, Barão Geraldo, Campinas, SP

13083-970, Brazil

${ }^{2}$ Department of Paediatrics, College of Medicine, Ekiti State University, Ado

Ekiti, Ekiti State, Nigeria

Full list of author information is available at the end of the article
}

(c) The Author(s). 2019 Open Access This article is distributed under the terms of the Creative Commons Attribution 4.0 International License (http://creativecommons.org/licenses/by/4.0/), which permits unrestricted use, distribution, and

reproduction in any medium, provided you give appropriate credit to the original author(s) and the source, provide a link to the Creative Commons license, and indicate if changes were made. The Creative Commons Public Domain Dedication waiver (http://creativecommons.org/publicdomain/zero/1.0/) applies to the data made available in this article, unless otherwise stated. 


\section{Introduction}

Sickle cell disease (SCD) is a common genetic disorder among Africans. Individuals with the disease have variable clinical expression but homozygosity for the $\mathrm{HbS}$ gene, also known as sickle cell anaemia (SCA), is the most severe form [1]. Children with SCA have chronic hemolysis, leading to accumulation of serum bilirubin and consequent gallstones [2]. Bilirubin is a tetrapyrol that results from the breakdown of heme in red blood cells. At moderate levels, it protects against oxidative stress and inflammatory injuries, and some infectious diseases [3-5]. However, excessive bilirubin levels, as seen in chronic hemolysis, have been linked to increased incidence of gallstones [1, 2, 5]. In children with SCA, this risk increases with advancing age with a cumulative incidence of approximately $50 \%$ by adulthood and some of them may need cholecystectomy [2, 6, 7].

Uridine diphosphate glucuronosyltransferase $1 \mathrm{~A}$ isoform 1 (UGT1A1) is a member of the superfamily of phase II conjugating enzymes that aids the elimination of bilirubin, drugs and a vast variety of endogenous and exogenous substrates by adding a glucuronide moiety to the substrates [8, 9]. Genetic mutations resulting in absence or severely reduced UGT1A1 activity leads to Criggler-Najjar syndrome which is characterized by severely elevated serum bilirubin and increased risk of kernicterus [10]. However, variations in (TA) $n$ tandem repeat sequence within the TATA box promoter region affect $U G T 1 A 1$ gene expression and the activity of its (TA) n four alleles, namely; (TA) 5, 6, 7, and 8 , leading to moderate elevation of serum bilirubin $[8,9]$. There is a negative association between the UGT1A1 and repeat length of the four alleles attributable to the decreasing promoter activity acting via altered affinity for the TATA-binding protein $[8,9]$. The promoter activity leads to functional changes such that, genotype (TA)5/5 is considered to have $\sim 20 \%$ increased expression i.e. high activity in comparison to genotype (TA) 6/6 known as the wildtype with normal activity. In addition, genotypes heterozygous and or homozygous for (TA)7 and (TA)8 alleles have approximately between 30 and 50\% reduced expression i.e. low activity, compared to the wild-type [8]. However, genotypes (TA)7/7, 7/8 \& 8/8 have the lowest activity [2, 8, 9] and (TA)7/7 has been described generally as genetic hallmark for Gilbert syndrome $[2,11]$. There is an inverse relationship between the serum bilirubin levels across these subgroups and the degree of genotype activity. To this end, individuals with low-activity genotypes have elevated levels of serum bilirubin and are, therefore, subjected to the modulating effects of higher serum bilirubin levels including susceptibility to gallstones $[2,8,9,11]$.

Despite the huge burden of SCA in Africa [1], with Nigeria having the highest burden of SCA in the world [12], there is little understanding of the contributions of genetic modifiers of SCA phenotypes in the country. To the best of our knowledge, there are no data on the effects of UGT1A1 polymorphisms on the clinical expression of Nigerian SCA patients. The aims of this study were to determine the distribution of UGT1A1 (TA) n genotypes among a group of young SCA patients and healthy controls and also determine the influence of the UGT1A1 (TA) n genotypes on the laboratory parameters and clinical events among the young SCA patients.

\section{Methods}

\section{Study participants and settings}

The study was conducted on 101 hydroxyurea-naïve children and adolescents with SCA (Homozygous SS) aged between 2 and 21 years (median of 9 years) who are regular attendees at the paediatric haematology unit of the Ekiti State University Teaching Hospital (EKSUTH), Ado Ekiti, Ekiti State, in Southwest Nigeria. They were all in steady state at the time of recruitment. Steady state was defined as being free from any acute event(s) for at least 1 month and transfusion free for at least 4 months. Sixty four genetically independent and unrelated children, who accompanied their siblings to or attended the paediatrics outpatients' well-child clinic of the hospital served as the controls. Participants with confirmed or suspected liver or other chronic diseases apart from SCA were excluded. Also excluded were the few SCA patients on regular blood transfusion and/or hydroxyurea.

\section{Ethical approval}

The study was approved by the Ethics and Research Committee of EKSUTH no: A67/2016/03/003. Because the DNA analysis was done at the hematology and hemotherapy centre, University of Campinas, the study was also approved by the University of Campinas Ethics Committee no: CAAE 54031115.9.0000.5404. Written informed consent of parents/caregivers as well as patients' assents and consents were obtained as applicable after explaining the purpose of the study to them in clear and plain language.

\section{Data collection \\ Clinical and laboratory data}

Information regarding the steady-state laboratory parameters and clinical events of the patients were retrieved from their hospital records. Average of at least two steady state results of laboratory parameters performed between 3 to 6 months intervals by standard techniques were recorded for each participants. The steady state parameters included the complete blood performed by Sysmex KX21N Hematology analyser (Sysmex Corporation, Kobe, Japan). The serum lactate dehydrogenase (LDH), bilirubin, were measured with standard techniques. The quantitative assessment of haemoglobin pattern $(\mathrm{HbF}$ and $\mathrm{HbS})$, was done by high 
performance liquid chromatography (HPLC, Bio-Rad Variant D10, USA).

Other information retrieved from patients' charts included the biodata and details of the clinical evolution of SCA such as number of vaso-occlussive crisis (VOC) i.e. severe bone pain crises that disrupt daily activities and required admission and/or administration of opioids within the preceding 1 year, leg ulcer, priapism, overt osteonecrosis and/or overt stroke as well as presence of gallstone as determined by serial abdominal ultrasound scans conducted on the patients as clinically indicated. In addition, the clinical records of the patients with gallstones were examined for the presence or absence of symptoms, and or treatment(s) for gallstone complications. The definitions of clinical events were as previously described [13].

\section{Genetic studies}

These were carried out at the Centro de Hematologia e Hemoterapia (Hemocentro), UNICAMP, Campinas, São Paulo State, Brazil. SCA was initially diagnosed by haemoglobin electrophoresis and high performance liquid chromatography (HPLC) in Nigeria.

The genomic DNA of each participant was extracted from peripheral blood leukocytes by Qiagen QIAamp DNA Blood Mini Kit, (Cat No. 51104 Germany), according to the manufacturer's protocols and used to confirm the molecular diagnosis of SCD by polymerase chain reaction (PCR). The DNA purity and concentration were evaluated on Nanodrop ND-1000 ${ }^{\text {ma }}$ Spectrophotometer (NanoDrop Technologies, Inc., DE, USA). PCR for exon 1 of HBB gene amplification was performed according to the following protocol in $30 \mu \mathrm{L}$ volume: $150 \mathrm{ng}$ of genomic DNA; $1 \mathrm{X}$ Colorless $\mathrm{GoTa}^{\circ}$ Flexi Reaction Buffer (Promega Corporation, Madison, USA); $2 \mathrm{mM} \mathrm{MgCl}_{2} ; 0.2 \mathrm{mM}$ of dNTP mix; $0.2 \mu \mathrm{M}$ of each primer (Integrated DNA Technologies, Coralville, Iowa) named P1: TCCTAAGCCAGTGC CAGAAG and P5: TCATTCGTCTGTTTCCCATTC [14] and $1 \mathrm{U}$ of $\mathrm{GoTaq}^{\circ}$ Flexi DNA Polymerase (Promega Corporation, Madison, USA). Thermal cycle conditions were as follow: preheating at $96^{\circ} \mathrm{C}$ for $2 \mathrm{~min}$, and then 35 cycles of amplification, with $30 \mathrm{~s}$ at $96^{\circ} \mathrm{C}$ for denaturation, $30 \mathrm{~s}$ at $58^{\circ} \mathrm{C}$ for annealing, and $60 \mathrm{~s}$ at $72^{\circ} \mathrm{C}$ for elongation. The PCR product $(771 \mathrm{bp})$ was submitted to sequencing reaction by the following conditions: $30 \mathrm{ng}$ PCR product, 1 , $0 \mu \mathrm{L}$ BigDye Terminator v3.1 Ready Reaction Mix (AppliedBiosystems, Foster City, CA, USA), 1X BigDye Reaction Buffer, $2 \mu \mathrm{M}$ of primer (P1 or P5). After thermal cycling (preheating at $96^{\circ} \mathrm{C}$ for $2 \mathrm{~min}$, followed by 25 cycles of $96^{\circ} \mathrm{C}$ for $15 \mathrm{~s}, 58^{\circ} \mathrm{C}$ for $5 \mathrm{~s}, 60^{\circ} \mathrm{C}$ for $4 \mathrm{~min}$ ), the sequencing reaction product was precipitated by ammonium acetate and ethanol method, dried at $65^{\circ} \mathrm{C}$ and re-suspended in $10 \mu \mathrm{L}$ of $\mathrm{Hi}$-Di Formamide for electrophoresis. Amplified fragments were separated by capillary electrophoresis on an ABI3500 Genetic Analyzer (Applied Biosystems, CA).

The UGT1A1 rs8175347 SNP identification was performed by Polymerase Chain Reaction (PCR) as previously described [15, 16], with some modifications. Briefly, the PCR reaction was prepared in $30 \mu \mathrm{L}$ volume with $100 \mathrm{ng}$ of genomic DNA; 1X Reaction Buffer (BIOTOOLS B\&M Labs, Spain); $2.16 \mathrm{mM} \mathrm{MgCl}$; $1.33 \mathrm{mM}$ of dNTP mix; 133 nM of each primer: UGT1A1_"F: 5'-FAM /GTCACGTGACACAGTCAAAC - 3' ("labelled with fluorescein amidite - 6-FAM) and UGT1A1_R: 5' CAACAGTATCTTCC CAGCATG - 3') (Integrated DNA Technologies, Coralville, Iowa), and $1 \mathrm{U}$ Taq DNA Polymerase (BIOTOOLS B\&M Labs, Spain). Thermal cycle conditions were as follow: preheating at $96^{\circ} \mathrm{C}$ by $2 \mathrm{~min}$, followed by 25 cycles of $96^{\circ} \mathrm{C}$ for $30 \mathrm{~s}, 58^{\circ} \mathrm{C}$ for $40 \mathrm{~s}$, and $72^{\circ} \mathrm{C}$ for $40 \mathrm{~s}$. An ended step at $72{ }^{\circ} \mathrm{C}$ for $30 \mathrm{~min}$ was performed to promote adenylation of the PCR products. Fragment analysis was performed by Capillary electrophoresis on ABI3500 Genetic Analyzer and sizes of amplicons were calculated by Gene Mapper v4.1 Software (both Applied Biosystems, Carlsbad, CA) - the fragments ranged from 197 to $203 \mathrm{bp}$, corresponding to $(\mathrm{TA})_{5}-(\mathrm{TA})_{8}$ repeats (Additional file 1: Figure $\mathrm{S} 1$ ). Based on literature data, the UGT1A1 (TA) n genotypes were further classified into four subgroups namely: Wild-type (normal), low-, intermediate-, and high-activity subgroups as previously described $[2,8,9,11]$. All DNA studies were carried out blinded regardless of the clinical and laboratory parameters of the participants.

\section{Data analysis}

Statistical analysis was performed with the GraphPad Prism Program, version 5 for Windows (San Diego, California, USA). The normal distribution of the quantitative variables was verified by the Kolmogorov-Smirnov and Shapiro-Wilk tests. The frequencies of variables were described and the significance of differences between quantitative variables across groups of patients was assessed using the Kruskal-Wallis analysis of variance (ANOVA) for $\geq 3$ groups, and Mann-Whitney test for two groups. Chi-square or Fisher's exact tests were used as appropriate for the categorical variables. Odd ratios were obtained by applying logistic regression to determine the effects of UGT1A1 promoter polymorphism using the UGT1A1 (TA) n genotype as the independent variable and other outcomes of interest as the dependent variables. The test for Hardy-Weinberg equilibrium was performed using the R-Project for statistical computing web tool available at https://www.R-project.org. Level of significance was set at $P<0.05$ for all statistical analyses.

\section{Results}

The 101 patients with SCA consisted of 66 males and 35 females with median age of 9 and a range $2-21$ years. 
The controls were made up of 19 sickle cell trait (HbAS) and 45 haemoglobin HbAA, median age of 8 , range 2 18 years $(p=0.4260)$, and 41 males. The SCA patients have been on follow up for a median of 4 years, range 114 years.

\section{UGT1A1 (TA) $\mathrm{n}$ alleles and genotypes}

Four (TA) n alleles: (TA) 5, 6, 7, and 8 were found with gene frequencies of $0.11,0.43,0.41$ and 0.05 respectively. The alleles were associated with 10 genotypes: TA5/5, 5/ $6,5 / 7,5 / 8,6 / 6,6 / 7,6 / 8,7 / 7,7 / 8,8 / 8$ (Table 1). The wild-type (normal) (TA) 6/6), low (TA) 7/7, 7/8, 8/8), intermediate (TA) 5/7,5/8,6/7,6/8), and high (TA) 5/5, $5 / 6$ ), enzyme activity genotypes were found in $24.8,24.8$, $41.5 \%, \& 8.9 \%$ patients and $20.3,15.6,61 \%$, \& $3.1 \%$ controls respectively. The low activity genotypes were found in $25(24.7 \%)$ patients and $10(15.6 \%)$ of the controls $(P=0.1773)$. Homozygous (TA) n TA7/7 was found in $22(21.7 \%)$ patients and $5(7.8 \%)$ controls $p=0.018$ (Table 1). The observed genotype distributions of the patients and control group were not significantly different from the values expected under Hardy-Weinberg equilibrium $\left(x^{2}=15.10, \mathrm{df}=9, p=0.09\right)$, and $\left(x^{2}=11.86\right.$, $\mathrm{df}=9, p=0.22)$, respectively.
Effects of UGT1A1 genotype on serum bilirubin and other laboratory parameters of patients

Both the total bilirubin and unconjugated bilirubin levels showed distinct quantitative patterns across the UGT1A1 (TA) $\mathrm{n}$ genotype subgroups with the lowactivity genotype group having the highest levels of serum bilirubin $(p<0.0001)$. The LDH also showed a similar pattern $(p=0.0002)$. However, this was not demonstrated in the other laboratory parameters (Table 2). The stratification of the individual UGT1A1 (TA) $\mathrm{n}$ genotypes separately shows that (TA)7 and (TA) 8 alleles were associated with higher levels of both serum bilirubin and LDH in general (Additional file 2: Table S1).

\section{Effects of UGT1A1 (TA) $\mathrm{n}$ genotype on clinical events}

Asymptomatic gallstones were found in $6(5.9 \%)$ patients. Gallstones were significantly more common in patients with low-activity genotypes compared to all the other remaining genotype subgroups $5(20 \%)$ vs $1(1.3 \%)$ $p=0.0033$, (Table 3). These were 2 females and 4 males; the two females were aged 10 and 13 years respectively, while the males were aged 10,13, 15 and 16 years respectively. Four of the patients with gallstone had TA 7/ 7 genotypes, the remaining two each had TA $7 / 8$, or TA

Table 1 Allele and genotype frequencies of UGT1A1 promoter polymorphisms among participants

\begin{tabular}{|c|c|c|c|}
\hline \multirow[t]{2}{*}{ Variables } & SCA $(N=101)$ & AS $(N=19)$ & $\mathrm{AA}(N=45)$ \\
\hline & Freq n (\%) & Freq n (\%) & Freq n (\%) \\
\hline \multicolumn{4}{|l|}{ Allelotypes } \\
\hline (TA) 5 & $18(11.7)$ & $2(6.7)$ & $10(12.5)$ \\
\hline (TA)6 & $67(43.5)$ & $16(53.3)$ & $28(35.0)$ \\
\hline (TA)7 & $61(39.6)$ & $10(33.3)$ & $37(46.2)$ \\
\hline$(T A) 8$ & $8(5.2)$ & $2(6.7)$ & $5(6.3)$ \\
\hline \multicolumn{4}{|l|}{ UGT1A1 Genotypes } \\
\hline TA5/5 & $0(0)$ & $0(0)$ & $1(2.2)$ \\
\hline TA5/6 & $9(8.9)$ & $0(0)$ & $1(2.2)$ \\
\hline TA5/7 & $6(6.0)$ & $1(5.2)$ & $8(17.7)$ \\
\hline TA5/8 & $3(2.9)$ & $0(0)$ & $0(0)$ \\
\hline TA6/6 & $25(24.7)$ & $8(42.1)$ & $5(11.1)$ \\
\hline TA6/7 & $31(30.7)$ & $7(36.8)$ & $21(46.7)$ \\
\hline TA6/8 & $2(2.0)$ & $1(5.2)$ & $1(2.2)$ \\
\hline TA7/7 & $22(21.7)$ & $1(5.2)$ & $4(8.9)$ \\
\hline TA7/8 & $2(2.0)$ & $1(5.2)$ & $4(8.9)$ \\
\hline TA8/8 & $1(1.0)$ & $0(0)$ & $0(0)$ \\
\hline \multicolumn{4}{|l|}{ UGT1A1 Genotypes by degree of Activity } \\
\hline Low-Activity genotypes TA $(7 / 7,7 / 8,8 / 8)$ & $25(24.8)$ & $2(10.5)$ & $8(17.8)$ \\
\hline Intermediate-Activity genotypes (TA6/7, TA6/8), TA5/7, TA5/8, & $42(41.5)$ & $9(47.4)$ & $30(66.7)$ \\
\hline Normal Activity genotypes i.e. (Wild Type) TA6/6 & $25(24.8)$ & $8(42.1)$ & $5(11.1)$ \\
\hline High-Activity genotypes TA5/5, TA5/6, & $9(8.9)$ & $0(0)$ & $2(4.4)$ \\
\hline
\end{tabular}


Table 2 Influence of UGT1A1 (TA) n genotype on laboratory parameters of patients

\begin{tabular}{|c|c|c|c|c|c|}
\hline Parameter & $\begin{array}{l}\text { a. Low activity } \\
\text { UGT1A1 genotypes } \\
N=25\end{array}$ & $\begin{array}{l}\text { b. Intermediate activity } \\
\text { UGT1A1 genotypes } \\
N=42\end{array}$ & $\begin{array}{l}\text { c. Normal activity UGT1A1 } \\
\text { genotypes (i.e Wild type) } \\
N=25\end{array}$ & $\begin{array}{l}\text { d. High activity UGT1A1 } \\
\text { genotypes } \\
N=9\end{array}$ & $\begin{array}{l}\text { Anova (Kruskal- } \\
\text { Wallis Test) } P \text { values } \\
\text { (a vs b vs C vs d) }\end{array}$ \\
\hline $\begin{array}{l}\text { Biochemical and } \\
\text { haematologic }\end{array}$ & Median (Range) & Median (Range) & Median (Range) & Median (Range) & \\
\hline Total Bilirubin (mg/dl) & $2.8(1.2-8.1)$ & $1.8(0.8-4.6)$ & $1.4(0.4-3.8)$ & $1.4(0.5-2.8)$ & $<0.0001 * * 1$ \\
\hline $\begin{array}{l}\text { Unconjugated Bilirubin (mg/ } \\
\text { dl) }\end{array}$ & $1.8(0.6-6.3)$ & $0.8(0.1-3.3)$ & $0.6(0.1-2.3)$ & $0.5(0.3-1.6)$ & $<0.0001^{* * 1}$ \\
\hline LDH (IU/L) & $987(296-1860)$ & $798(215-1489)$ & $789(340-1417)$ & $287(197-800)$ & $0.0002^{* * 2}$ \\
\hline AST (IU/L) & $46(18-89)$ & $37(8-89)$ & $42(7-89)$ & $39(18-89)$ & $0.4837^{* *}$ \\
\hline ALT (IU/L) & $25(4-65)$ & $19(7-77)$ & $20(7-44)$ & $12(4-34)$ & $0.216^{* *}$ \\
\hline $\mathrm{Hb}$ conc $(\mathrm{g} / \mathrm{dl})$ & $7.3(6.3-10)$ & $7.5(6.3-9.7)$ & $7.2(6.2-10)$ & $7.9(7-8.8)$ & $0.608^{* *}$ \\
\hline $\mathrm{MCV}(\mathrm{fl})$ & $80.6(66.9-104.1)$ & $82.3(60.3-10.2)$ & 77.3 (63.9-96.3) & $81(55.9-115)$ & $0.642^{* *}$ \\
\hline $\mathrm{RBC}\left(\times 10^{12} / \mathrm{L}\right)$ & $2.7(1.9-4.1)$ & $2.7(1.8-4.1)$ & $2.9(1.8-4.8)$ & $2.8(2.2-3.9)$ & $0.258^{* *}$ \\
\hline WBC $\left(\times 10^{9} / \mathrm{L}\right)$ & $13(8.5-26)$ & $13.4(6.1-29.3)$ & $13.3(7-25)$ & $12.2(7.6-23.1)$ & $0.889 * *$ \\
\hline Platelet $\left(\times 10^{9} / \mathrm{L}\right)$ & $367(118-771)$ & $349(159-601)$ & $361(108-669)$ & $391(135-832)$ & $0.955^{* *}$ \\
\hline $\mathrm{HbF}(\%)$ & $9.7(1.3-20.6)$ & $8.2(1.7-24.4)$ & $10.7(2.5-32)$ & $9.4(0.9-28.5)$ & $0.86^{* *}$ \\
\hline $\mathrm{HbS}(\%)$ & $80(71-91.5)$ & $82(44-91.5)$ & $80(44-88.3)$ & $80(65-89)$ & $0.90 * *$ \\
\hline $\mathrm{HbA2}(\%)$ & $1.6(0.5-3.5)$ & $1.7(0.2-3.8)$ & $1.5(0.2-4.0)$ & $1.1(0.3-3.1)$ & $0.3147^{* *}$ \\
\hline
\end{tabular}

Significant $p$ values are indicated in bold fonts

$H b F$ Fetal hemoglobin, RBC Red blood cell, $H b$ Hemoglobin concentration, HbS Hemoglobin S, HbA2 Hemoglobin A2, MCV Mean corpuscular volume, WBC White blood cell count, $L D H$ Lactate dehydrogenase, AST Aspartate transaminase, ALT Alanine transaminase

${ }^{* *}=$ Kruskal-Wallis Test with Dunn's multiple comparison post-hoc tests with differences in * 1 = (a vs b), (a vs c), (a vs d) only; ${ }^{*} 2=(a$ vs d), (b vs d), (c vs d) only

6/7. No significant relationship was found with the other clinical events.

\section{Comparison of laboratory parameters between patients with and without gallstones}

There were significant differences between the serum bilirubin and HbF levels in patients with gallstones when compared with those without. No difference was observed in the LDH and age of the two groups. Furthermore, when those with gallstones were compared with age- and sex-matched patients within the same UGT1A1 (TA) $\mathrm{n}$ genotype subgroup, only serum bilirubin and $\mathrm{HbF}$ showed significant differences between the two groups (Table 4).

Table 3 Influence of UGT1A1 (TA) n genotype on clinical events of patients

\begin{tabular}{|c|c|c|c|c|c|}
\hline Clinical events & $\begin{array}{l}\text { a. Low activity } \\
\text { UGT1A1 genotypes } \\
N=25\end{array}$ & $\begin{array}{l}\text { b. Intermediate activity } \\
\text { UGT1A1 genotypes } \\
N=42\end{array}$ & $\begin{array}{l}\text { c. Normal activity UGT1A1 } \\
\text { genotypes (Wild Type) } \\
N=25\end{array}$ & $\begin{array}{l}\text { d. High activity } \\
\text { UGT1A1 genotypes } \\
N=9\end{array}$ & $\begin{array}{l}P \text { value a vs } \\
(b+c+d)\end{array}$ \\
\hline VOC rate per year & $2(0-6)$ & $1.5(0-6)$ & $1(0-6)$ & $0(0-6)$ & $0.2218^{*}$ \\
\hline Overt Stroke & 1 & 2 & 1 & 0 & $1.000+$ \\
\hline No overt stroke & 24 & 40 & 24 & 9 & \\
\hline Osteonecrosis & 1 & 2 & 2 & 0 & $1.000+$ \\
\hline No osteonecrosis & 24 & 40 & 23 & 9 & \\
\hline Leg ulcer & 0 & 2 & 4 & 0 & $0.331 \dagger$ \\
\hline No Leg ulcer & 25 & 40 & 21 & 9 & \\
\hline Gallstones & 5 & 1 & 0 & 0 & $0.0033 \dagger$ \\
\hline No Gallstone & 20 & 41 & 25 & 9 & \\
\hline \multicolumn{6}{|c|}{ Priapism (Male only event, $N=66$ ) } \\
\hline Priapism & 2 & 3 & 0 & 0 & $0.594 \dagger$ \\
\hline No Priapism & 15 & 25 & 16 & 5 & \\
\hline
\end{tabular}

Significant $p$ values are indicated in bold fonts VOC Vaso-occlussive crisis

* = Mann-Whitney Test, $+=$ Fisher's exact test 
Table 4 Comparison of parameters in patients with and without gallstones

\begin{tabular}{|c|c|c|c|}
\hline Parameter & $\begin{array}{l}\text { Patients with gallstones }(N=6) \\
\text { Median (Range) }\end{array}$ & $\begin{array}{l}\text { Patients without gallstones }(N=95) \\
\text { Median (Range) }\end{array}$ & $P$ value \\
\hline Total Bilirubin (mg/dl) & $6.4(2.8-8.1)$ & $1.8(0.4-6.7)$ & $0.0001^{*}$ \\
\hline Unconjugated Bilirubin (mg/dl) & $4.7(0.9-6.3)$ & $0.79(0.1-5)$ & $0.0007^{*}$ \\
\hline $\mathrm{LDH}(\mathrm{IU} / \mathrm{L})$ & $1004(592-1860)$ & $794(197-1750)$ & $0.1263^{*}$ \\
\hline $\mathrm{HbF}(\%)$ & $4.7(1.3-6.8)$ & $10.2(0.9-32)$ & $0.0107^{*}$ \\
\hline $\mathrm{Hb}(\mathrm{g} / \mathrm{dl})$ & $7.1(6.3-8.8)$ & $7.5(6.2-10)$ & $0.4210^{*}$ \\
\hline Age in years & $11.5(8-16)$ & $9(2-21)$ & $0.1368^{*}$ \\
\hline \multicolumn{4}{|l|}{ Sex } \\
\hline Male $(n=66)$ & 4 & 62 & \multirow[t]{2}{*}{$1.000+$} \\
\hline Female $(n=35)$ & 2 & 33 & \\
\hline Parameter & $\begin{array}{l}\text { Patients with gallstones }(N=6) \\
\text { Median (Range) }\end{array}$ & $\begin{array}{l}\text { Matched peers without gallstones within } \\
\text { same UGT1A1 genotype activity group } N=10 \\
\text { Median (Range) }\end{array}$ & $P$ value \\
\hline Total Bilirubin (mg/dl) & $6.4(2.8-8.1)$ & $2.2(1.9-3.2)$ & $0.0023^{*}$ \\
\hline Unconjugated Bilirubin (mg/dl) & $4.7(0.9-6.3)$ & $1.2(1.0-2.0)$ & $0.0020^{*}$ \\
\hline LDH (IU/L) & $1004(592-1860)$ & $890(340-1603)$ & $0.628^{*}$ \\
\hline $\mathrm{HbF}(\%)$ & $4.7(1.3-6.8)$ & $14.7(4.2-17.9)$ & $0.022^{*}$ \\
\hline $\mathrm{Hb}(\mathrm{g} / \mathrm{dl})$ & $7.1(6.3-8.8)$ & $8.0(6.5-8.9)$ & $0.137^{*}$ \\
\hline
\end{tabular}

NB Significant $P$ values are indicated in bold fonts

$\mathrm{HbF}$ Fetal hemoglobin, $\mathrm{Hb}$ Hemoglobin concentration, $\mathrm{LDH}$ Lactate dehydrogenase

* = Mann-Whitney test, $+=$ Fisher's Exact test

\section{Relationship between UGT1A1 (TA) $\mathrm{n}$ genotypes and other parameters by multivariate analysis}

Unconjugated bilirubin was significantly associated with the low activity UGT1A1 (TA) n genotypes (Adjusted Odd Ratio (1.08), 95\% Confidence interval (1.0347681.127873), $P<0.0001)$. Also, significant association was found with the total bilirubin when it was used in place of unconjugated bilirubin in the logistic regression model (Adjusted Odd Ratio (1.05), 95\% Confidence interval (1.029172-1.089832), $P<0.0001)$. No association was found with the other laboratory parameters.

\section{Discussion}

There are gaps in the understanding of the impacts of genetic modifiers on SCA phenotype among African patients. Given the distinct segregation of genetic markers among different populations, it is pertinent that more studies are carried out among diverse ethnic cohorts to fully understand the impact of genetic polymorphisms in SCA.

This study confirms the variability of bilirubin levels based on the activity of the UGT1A1 (TA) n genotypes as previously reported $[2,4,5,8,9]$. However, we are not aware of any previous study that has described the stratification of LDH among SCA patients based on UGT1A1 (TA) $\mathrm{n}$ genotype activity as found in this study. While the UGT1A1 modulation of serum bilirubin levels is well understood [2, 17, 18], the exact mechanism through which UGT1A1 could be associated with LDH is not clear. However, it should be noted that they are both markers of hemolysis [19]. Given the association of LDH with some phenotypes of SCA $[19,20]$, there is need to further unravel the link between LDH and UGT1A1 activity.

Gilbert syndrome (GBS) has been described in individuals with the TA7/7 genotype $[2,4,11,17]$. The proportion of patients with TA7/7 genotype in this study (21.7\%) is higher than between 3 and 18\% described among Europeans [21, 22] and Brazilians of different descents [23-25]. Similarly, it is higher than the $6 \%$ found among Kuwaiti SCA patients [26] and the 5 to $11 \%$ among other Africans $[11,22]$. However, it is lower than the $32 \%$ described among the SCA patients in the USA [27]. Nevertheless, the TA7/7 genotype prevalence in this study, is comparable to between 18.2 and $20.3 \%$ earlier described among Nigerians with non-SCD related illnesses [28, 29]. However, the higher preponderance of TA7/7 among the patients compared to the controls in the present study is not clear but may be due to the low sample size.

Besides the TA7/7 genotype, the other UGT1A1 (TA) n genotypes found in this study have been described among Africans [9, 22]. These observations indicate that the UGT1A1 (TA) n genotype is quite variable among Nigerians. It also confirms the suggestions that the expression of the UGT1A1 (TA) n genotype variants is heterogeneous among Africans compared to Caucasians [9, 21, 22].

Our finding that the low-activity UGT1A1 (TA) n genotype was associated with gallstones confirms previous observations that SCA patients with the low-activity UGT1A1 (TA) n genotypes especially the TA7/7, are at 
risk of developing gallstones [2, 6, 7, 11, 17]. In addition to the TA7/7 genotype, other authors $[11,30]$, have reported that some other low-activity UGT1A1 (TA) n genotypes like TA7/8 and TA8/8 predispose SCA patients to gallstones as found in this study.

The proportion of patients with asymptomatic gallstones in this study (5.9\%), is comparable to between 4 and 6\% earlier reported among Nigerian children of similar age to our SCA cohorts [31-33]. This is also similar to the $4 \%$ found in Ghana [34], a close neighbour to Nigeria. However, it is lower than between 9 and $58 \%$ reported for some other African [35-37], Italian [38], American [39], and Brazilian [40] patients. These observations possibly highlight the variations in propensity to gallstone development among children with SCA from different backgrounds.

Despite the observation that the UGT1A1 (TA) n low -activity genotype is a leading factor in hyperbilirubinemia and lithogenesis among SCA patients [2, 6, 7, 41, 42], the impact of UGT1A1 polymorphism on the phenotypic expression of the Nigerian SCA patients was unknown prior to this study as none of the previous studies from Nigeria examined the UGT1A1 of the patients [31-33]. There is therefore, the need to closely follow up these patients given that, results of follow-up studies have indicated higher prevalence of gallstones and its complications with increasing age of SCA patients [2, 26, 30, 37, 40].

Beyond bilirubin metabolism and gallstone development, it has been speculated that individuals with the lowactivity genotypes may be subjected to some other modulating effects of higher serum bilirubin levels that are often associated with these genotypes $[2,8,9,11]$. These other modulating effects include protection against oxidative stress, inflammatory injuries, and reduced susceptibility to infections $[2-5,8,9,43]$. We did not observe any association between the UGT1A1 (TA) $\mathrm{n}$ genotypes and any of the other SCA downstream events/phenotypes examined (VOC, leg ulcer, priapism, overt stroke and osteonecrosis) that could be perturbed by both inflammatory and oxidative injuries in SCA. However, the small sample size of the study makes it difficult to draw any firm conclusion.

The major limitations of the present study are its hospital-based nature and the small sample. Despite these, it was able to confirm that UGT1A1 (TA) n genotypes are tightly associated with bilirubin and LDH levels, and the development of gallstones among young Nigerians with SCA. In addition, it also suggests that the pathway to elevated serum bilirubin and gallstone development, among our study cohort, may not be exclusively driven by hemolysis but also by UGT1A1 polymorphisms.

\section{Conclusions}

This study shows that children with co-inheritance of low UGT1A1 (TA) $\mathrm{n}$ affinity genotypes may be at risk of gallstone, thus highlighting the need to closely follow them up for early identification of possible gallstone complications and provision of appropriate intervention(s). In addition, it highlights the contribution of UGT1A1 polymorphisms, a non-globin genetic factor, to the laboratory and clinical manifestations of young $\mathrm{Ni}$ gerian SCA patients for the first time.

\section{Supplementary information}

Supplementary information accompanies this paper at https://doi.org/10. 1186/s12881-019-0899-3.

Additional file 1: Figure S1. Supplement material for UGT1A polymorphism in young Nigerians with SCA.

Additional file 2: Table S1. UGT1A1 genotypes distribution with their bilirubin and LDH levels among patients.

\section{Abbreviations}

EKSUTH: Ekiti State University Teaching Hospital; GBS: Gilbert syndrome; HbF: Fetal hemoglobin; HPLC: High performance liquid chromatography; LDH: Lactate dehydrogenase; PCR: Polymerase chain reaction; SCA: Sickle cell anaemia; SCD: Sickle cell disease; UGT1A1: Uridine Diphosphate Glucuronosyl Transferase 1A; UNICAMP: University of Campinas; VOC: Vaso-occlussive crisis

\section{Acknowledgements}

Authors acknowledge with thanks the support received from participants and their caregivers/parents during the study. We also acknowledge with thanks, the laboratory supports provided by Prof Adeyinka Gladys Falusi of the Institute for Advanced Medical Research and Training, College of Medicine, University of Ibadan, Southwest Nigeria.

\section{Authors' contributions}

All authors contributed to critical aspects of the study. OSO, AA, and FFC, conceived and designed the study. OSO Wrote the paper, participated in data collection, analysis, patients' management and follow up. GOA \& OSA performed the ultrasound scans. DMA \& DPL, performed the genetic studies. ABT, OAF, \& TSK data collection \& analysis. FFC supervised the study. All authors participated in reviewing the manuscript for important intellectual contents and agreed to the final version.

\section{Funding}

This study was supported by grants No 2014/00984-3 from FAPESP, and grants No 2015/141693-0 from CNPq, Brazil. The funding bodies played no role in the design of the study and collection, analysis, and interpretation of data, and in writing the manuscript.

\section{Availability of data and materials}

The datasets generated and or analysed during the current study are available from the corresponding author on a reasonable request.

\section{Ethics approval and consent to participate}

The study was performed according to the Declaration of Helsinki on research involving human subjects. The study was approved by the Ethics and Research Committee of EKSUTH no: A67/2016/03/003. Because the DNA analysis was done at the hematology and hemotherapy centre, University of Campinas, the study was also approved by the University of Campinas Ethics Committee no: CAAE 54031115.9.0000.5404. Written informed consent of parents/caregivers as well as patients' assents and consents were obtained as applicable after explaining the purpose of the study to them in clear and plain language.

\section{Consent for publication}

Not applicable.

Competing interests

The authors declare that they have no competing interests. 


\section{Author details}

${ }^{1}$ Hematology and Hemotherapy Center (Hemocentro), University of Campinas (UNICAMP), Rua Carlos Chagas, 480, Barão Geraldo, Campinas, SP 13083-970, Brazil. ²Department of Paediatrics, College of Medicine, Ekiti State University, Ado Ekiti, Ekiti State, Nigeria. ${ }^{3}$ Department of Radiology, College of Medicine, Ekiti State University, Ado Ekiti, Nigeria. ${ }^{4}$ Department of Paediatrics, Ekiti State University Teaching Hospital, Ado Ekiti, Nigeria. ${ }^{5}$ Department of Medical Biochemistry, College of Medicine, Ekiti State University, Ado Ekiti, Nigeria. ${ }^{6}$ Department of Chemical Pathology, Ekiti State University Teaching Hospital, Ado Ekiti, Nigeria. ${ }^{7}$ Department of Pediatrics, Faculty of Medicine, Kuwait University, Jabriya, Kuwait.

Received: 16 April 2019 Accepted: 30 September 2019 Published online: 16 October 2019

\section{References}

1. Rees DC, Williams TN, Gladwin MT. Sickle cell disease. Lancet. 2010;376:2018-31.

2. Carpenter SL, Lieff S, Howard TA, Eggleston B, Ware RE. UGT1A1 promoter polymorphisms and the development of hyperbilirubinemia and gallbladder disease in children with sickle cell anemia. Am J Hematol. 2008;83:800-3.

3. Stocker R, Yamamoto Y, McDonagh A, Glazer A. Bilirubin is an antioxidant of possible physiological importance. Science. 1987;235:1043-6.

4. Schwertner HA, Vitek L. Gilbert syndrome, UGT1A1*28 allele, and cardiovascular disease risk: possible protective effects and therapeutic applications of bilirubin. Atherosclerosis. 2008;198:1-11.

5. Italia KY, Jijina FF, Jain D, Merchant $R$, Nadkarni AH, Mukherjee M, et al. The effect of UGT1A1 promoter polymorphism on bilirubin response to hydroxyurea therapy in haemoglobinopathies. Clin Biochem. 2010;43:1329-32.

6. Ware R, Filston HC, Schultz WH, Kinney TR. Elective cholecystectomy in young patients with sickle hemoglobinopathies. Ann Surg. 1988;208:17-22.

7. Haberkern CM, Neumayr LD, Orringer EP, et al. Cholecystectomy in sickle cell anemia patients: perioperative outcome of 364 cases from the national preoperative transfusion study. Blood. 1997;89:1533-42.

8. Guillemette C. Pharmacogenomics of human UDP-glucuronosyltransferase enzymes. Pharmacogenomics J. 2003;3(3):136-58.

9. Horsfall LJ, Zeitlyn D, Tarekegn A, Bekele E, Thomas MG, Bradman N, et al. Prevalence of clinically relevant UGT1A1 alleles and haplotypes in African population. Ann Hum Genet. 2011;75:236-46.

10. Kadakol A, Ghosh SS, Sappal BS, et al. Genetic lesions of bilirubin uridinediphosphoglucuronate glucuronosyltransferase (UGT1A1) causing CrigglerNajar and Gilbert syndromes: correlation of genotype to phenotype. Hum Mutat. 2000;16:297-306.

11. Chaouch L, Talbi E, Moumi I, Chaabene AB, Kalai M, Chaouachi D, et al. Early complication in sickle anemia children due to A (TA) n TAA polymorphism at the promoter of UGT1A1 gene. Dis Markers. 2013;35(2):67-72.

12. Diakwu-Akinwumi IN, Abubakar SB, Adegoke SA, Adeleke S, Adewoye O, Adeyemo T, et al. Blood transfusion services for patients with sickle cell disease in Nigeria. Int Health. 2016;8(5):330-5.

13. Ballas SK, Lieff S, Benjamin LJ, Dampier CD, Heeney MM, Hope C. Definitions of phenotypic manifestations of sicle cell disease. Am J Hematol. 2010;85:6-13.

14. Miranda SRP, Fonseca SF, Figueiredo MS, Grotto HZW, Kimura EM, Saad STO, et al. Hb Köln [ $a_{2} \beta_{2} 98(F G 5)$ val-met] identified by DNA analysis in a Brazilian family. Braz J Genet. 1997;20(4):745-8.

15. Mezzacappa MA, Facchini FP, Pinto AC, Cassone AEL, Souza DS, Bezerra MAC, et al. Clinical and genetic risk factors for moderate hyperbilirubinemia in Brazilian newborn infants. J Perinatol. 2010;30(12):819-26.

16. Abou Tayoun AN, de Abreu FB, Lefferts JA, Tsongalis GJ. A clinical PCR fragment analysis assay for TA repeat sizing in the UGT1A1 promoter region. Clin Chim Acta. 2013;422:1-4.

17. Hamad Z, Aljedai A, Halwani R, Alsultan A. UGT1A1promoter polymorphism associated with serum bilirubin level in Saudi patients with sickle cell disease. Ann Saudi Med. 2013;33(4):372-6.

18. Haverfield EV, McKenzie CA, Forrester, et al. UGT1A1 variation and gallstone formation in sickle cell disease. Blood. 2005;105(3):968-72.

19. Damanhouri GA, Jarullah J, Marouf S, Hindawi SI, Mushtaq G, Kamal MA. Clinical biomarkers in sickle cell disease. Saudi J Biol Sci. 2015;22:24-31.

20. Kato GJ, McGowan V, Machado RF, Little JA, Taylor VIJ, et al. Lactate dehydrogenase as a biomarker of hemolysis-associated nitric oxide resistance, priapism, leg ulceration, pulmonary hypertension, and death in patients with sickle cell disease. Blood. 2006;107(6):2279-85.
21. Beutler E, Gelbart T, Demina A. Racial variability in the UDPglucuronosyltransferase1 (UGT1A1) promoter: a balanced polymorphism for the regulation of bilirubin metabolism? Proc Natl Acad Sci. 1998;95:8170-4.

22. Premawardhena A, Fisher CA, Liu YT, et al. The global distribution of length polymorphisms of the promoters of the glucuronoslytransferase 1 gene (UGT1A1): hematologic and evolutionary implications. Blood Cells Mol Dis. 2003;31:98-101.

23. Fertrin KY, Goncalves MS, Saad STO, Costa FF. Frequencies of UDPGlucuronosyltransferase 1 (UGT1A1) gene promoter polymorphisms among distinct groups from Brazil. Am J Med Genet. 2002;108:117-9.

24. Fertrin KY, Melo MB, Assis AM, Saad STO, Costa FF. UDP-glucuronosyltransferase 1 gene promoter is associated with increased serum bilirubin levels and cholecystectomy in patients with sickle cell anemia. Clin Genet. 2003;64:160-2.

25. Azevedo LA, Santin AP, Wagner SC, Zaleski CF, Bock H, Saiva-Pereira ML, et al. Prevalence of UGT1A1 gene polymorphism in patients with haemolytic anemia in southern Brazil. Genet Test Mol Biomarkers. 2011;15(1\&2):107-10.

26. AlFadhil S, Al-Jafer H, Hadi M, Al-Mutairi M, Nizam R. The effect of UGT1A1 promoter polymorphism in the development of hyperbilrubinemia and cholelithiasis in hemoglobinopathy patients. PLoS One. 2013;8(10):e77681. https://doi.org/10.1371/journal.pone.0077681.

27. Adekile A, Kutlar F, McKie K, Addington A, Elam D, Holley L, et al. The influence of uridine diphosphate glucuronosyl transferase $1 \mathrm{~A}$ promoter polymorphisms, $\beta^{\mathrm{s}}$ globin gene haplotype and co-inherited $\alpha$-thalassemia trait and $\mathrm{HbF}$ on steady state serum bilirubin levels in sickle cell anemia. Eur J Haematol. 2005;75:150-5.

28. Huo D, Kim H, Adebamowo CA, Ogundiran TO, Akang E, et al. Genetic polymorphisms in uridine diphosphoglucuronosyltransferase $1 \mathrm{~A} 1$ and cancer risks in Africans. Breast Cancer Res Treat. 2008;110:367-76.

29. Kaplan M, Slusher T, Renbaum P, Essiet DF, Pam S, Levy-Lahad E, et al. (TA) n UDP-Glucuronosyltransferase1a1 promoter polymorphism in Nigerian neonates. Pediatr Res. 2008;63:109-11.

30. Chaar V, Keclard L, Diara JP, Leturdu C, Elion J, Krishnamoorthy R, et al. Association of UGT1A1 polymorphism with prevalence and age of onset of cholelithiasis in sickle cell anemia. Haematological. 2005;90(2):188-93.

31. Adekile AD, Makanjuola D. Ultrasonography in children with sickle cell anemia. Niger J Paediatr. 1983;10:35-8.

32. Nzeh DA, Adedoyin MA. Sonographic pattern of gallbladder disease in children with sickle cell anemia. Pediatr Radiol. 1989;19(5):290-2.

33. Odunvbun ME, Adeyekun AA. Ultrasonic assessment of the prevalence of gallstones in sickle cell disease children seen at the University of Benin Teaching Hospital, Benin City, Nigeria. Niger J Paed. 2014;41(4):370-4.

34. Darko R, Rodrigues OP, Oliver-Commey JO, Kotei CN. Gallstones in Ghanian children with sickle cell disease. West Afr J Med. 2005;24(4):295-8.

35. Longo-Mbenza B, Ngiyulu R, Kizunda P, Kaluila M, Bikangi N. Gallbladder disease in young Congolese with sickle cell anemia: an ultrasound survey. J Trop Pediatr. 2004;5:73-7.

36. Attalla Bl. Sonographic findings in Sudanese children with sickle cell anemia J Diagn Med Sonogr. 2010;26:276-80.

37. Attalla BAI, Karrar ZA, Ibnouf G, Mohamed AO, Abdelwahab O, Nasir EM, et al. Outcome of cholelithiasis in Sudanese children with sickle cell anemia after a 13 years follow up. Afr Health Sci. 2013;13(1):154-9.

38. Russo-Mancuso G, Romeo MA, Guardabasso V, Schiliro G. Survey of sickle cell disease in Italy. Haematologica. 1998;83:875-81.

39. Passon RG, Howard TA, Zimmerman SA, Schultz WH, Ware RE. Influence of bilirubin Uridine Diphosphate Glucuronoslytransferase 1A promoter polymorphisms on serum bilirubin levels and cholelithiasis in children with sickle cell anemia. J Pediatr HematolOncol. 2001;23:448-51.

40. Gumeiro APS, Bellomo-Brandao MA, Costal-Pinto EAL. Gallstones in children with sickle cell disease followed up at a Brazillian hematology center. Arq Gastroenterol. 2008;45(4):313-8.

41. Martins R, Morais A, Dias A, Soares I, Rolao C, Ducla-Soares JL, et al. Eearly modification of sickle cell disease clinical course by UDP-glucuronosyltransferase 1A1 gene promoter polymorphism. J Hum Genet. 2008:53(6):524-8.

42. Milton JN, Sebastiani P, Solovieff N, Hartley SW, Bhatnagar P, Arking DE, et al. A genome-wide association study of total bilirubin and cholelithiasis risk in sickle cell anemia. PLoS One. 2012;7(4):e34741. https://doi.org/10.1371/journal.pone.0034741.

43. Kumar S, Guha M, Choubey V, Maity P, Srivastava K, Puri S, et al. Bilrubin inhibits plasmodium falciparum growth through the generation of reactive oxygen species. Free Radic Biol Med. 2008;44:602-13.

\section{Publisher's Note}

Springer Nature remains neutral with regard to jurisdictional claims in published maps and institutional affiliations. 